\title{
Migrant worker policies and national privilege: A UK case study
}

\author{
Políticas de trabajadores migrantes y privilegio nacional: \\ El caso del Reino Unido
}

Pier-Luc Dupont

University of Bristol

pierlucdt@gmail.com

doi: http://dx.doi.org/10.18543/djhr.2114

Submission date: 10.02 .2021

Approval date: 14.05.2021

Citation/Cómo citar: Dupont, Pier-Luc. 2021. "Migrant worker policies and national privilege: a UK case study». Deusto Journal of Human Rights, No. 7: 13-36. doi: http://dx.doi.org/10.18543/djhr.2114.

Summary: Introduction. 1. Structural injustice, social connection and international mobility. 2. Equality principles in migrant worker governance. 3. Maldistribution/exploitation. 4. Misrepresentation/ domination. 5. Misrecognition/stigmatisation. Conclusion. Bibliography.

Abstract: After a long period of decline in the Global North, migrant worker policies are making a comeback on the agenda of the European Union and several of its member states. Inspired by Iris Marion Young and Nancy Fraser's accounts of structural injustice, this article argues that such policies cannot be reconciled with the principle of equality between migrant and national workers enshrined in international legal instruments such as the Convention on Migrant Workers and the EU Seasonal Workers Directive. To make this point it draws on a selection of UK based empirical literature as well as primary data from a recent study on domestic workers admitted to the UK under temporary visas since 1998. Results suggest that such visas tend to push migrants' working conditions downwards (exploitation); prevent them from changing employer, enforcing rights in court or mobilising in unions (domination); and ultimately exacerbate racial conflict and stereotyping (stigmatisation).

Keywords: migrant workers; human rights; discrimination; racism; exploitation; domination

Resumen: Tras un largo declive en el Norte Global, las políticas de trabajadores migrantes han vuelto a la agenda de la Unión Europea y de varios de sus Estados miembros. Inspirado en las concepciones de la injusticia estructural de Iris Marion Young y Nancy Fraser, este artículo sostiene que 
estas políticas no pueden reconciliarse con el principio de igualdad entre trabajadores migrantes y nacionales recogido en instrumentos jurídicos internacionales como el Convenio de Naciones Unidas sobre los trabajadores migrantes y la Directiva de la UE sobre trabajadores temporales. El argumento se apoya en una selección de estudios empíricos realizados en el Reino Unido, así como datos primarios sobre trabajadoras domésticas admitidas en el Reino Unido bajo visados temporales desde 1998. Los resultados sugieren que estos visados contribuyen a empeorar las condiciones de trabajo de los migrantes (explotación); a impedirles que cambien de empleador, a que hagan cumplir sus derechos en los tribunales o se afilien a un sindicato (dominación); y, en última instancia, a exacerbar los conflictos raciales y los estereotipos (estigmatización).

Palabras clave: trabajadores migrantes; derechos humanos; discriminación; racismo; explotación; dominación 


\section{Introduction: The UK case ${ }^{1}$}

After decades of near abandonment in the Global North, Global South migrant worker policies have recently come back on the agenda of several governments and international organisations. A clear indicator of this trend is the adoption in 2014 of the EU Seasonal Workers Directive, ${ }^{2}$ whose preamble stresses migrants' potential contribution to economic competitiveness and the need for 'flexible immigration policies' to tap such potential. Starting from this premise, the Directive sets out to ensure 'decent working and living conditions for seasonal workers' as well as to prevent 'overstaying or temporary stay from becoming permanent'. By associating seasonal work to sectors where demand for labour rises at certain times of the year, and by leaving member states wide discretion to identify these sectors, the Directive gives the concept of seasonal worker a decidedly broad scope (Fudge and Olsson 2014, 448-449). Yet its explicit flagging of agriculture and tourism also suggests a focus on precarious and devalued occupations (Fudge and Olsson 2014, 440, 444; Medland 2017). In this sense the Directive encloses important parallels with the guest worker policies developed in Europe between World War II and the 1973-1974 oil crisis (Castles 2006), which have been widely criticised for failing to prevent permanent settlement and uphold migrant rights (Ruhs 2006). Its rationale of facilitating the shortterm mobility of workers from low-wage to high-wage economies also mirrors that of the Posted Workers Directive adopted in 1996 to regulate the transfer of workers employed in an EU member state, often in the less wealthy South and East, to another member state, often in the wealthier North-West. Since 2010, a dramatic rise in the prevalence of posted work and fraudulent arrangements to circumvent local labour standards has spurred the adoption of two new Directives respectively improving the enforcement of the 1996 standards and the

1 This article belongs to the research project "Towards a European Theory of Justice and Fairness (ETHOS)", funded by the European Union's Horizon 2020 Framework Programme under grant number 727112. It draws on excerpts previously published within Dupont (2018). I would like to thank Leila Celis for the permission to translate and reuse the material. I would also like to thank Bridget Anderson for coordinating the fieldwork and Tonia Novitz, Diego Acosta and Leanne Weber, as well as two anonymous reviewers, for helpful feedback on the first draft of the article.

2 Directive 2014/36/eu of the European Parliament and of the Council of 26 February 2014 on the conditions of entry and stay of third-country nationals for the purpose of employment as seasonal workers. 
standards themselves (Van Nuffel and Afanasjeva 2019; Novitz and Andrijasevic 2020, 1-2).

This article offers socio-legal reasons to think that contemporary migrant worker policies, like their historical precursors, reinforce the global dynamics of national privilege and racial oppression set off by European colonialism and imperialism (Fanon 1952; Mills 1997), which live on in contemporary forms of state-backed capitalism and cultural production (Balibar and Wallerstein 1991; Goldberg 1993). The argument draws on a selection of UK based empirical literature as well as primary data from a recent study on domestic workers admitted to the UK under temporary visas since 1998 (Dupont and Anderson 2018). Conducted as part of the Horizon 2020 project ETHOS - Toward a European theory of justice and fairness, the study interpreted available theory and data on UK labour and migration law through the lens of individual employment experiences collected through semi-structured interviews. While the experiences exposed here, taken from two interviews, cannot be mechanically extrapolated to all migrant workers, they can illuminate in a grounded and tangible way key problems facing those who are legally employed in low-paid occupations. The focus on this particular category of migrant workers, rather than on their undocumented or highly paid counterparts, is due to the renewed interest they have recently aroused among European policymakers, as well as to the reduced bargaining power that makes their working conditions highly sensitive to the legal rights they are able to exercise.

To put interviewees' experiences into context it may be useful to go four decades back. Between 1977 and 1998, migrant domestic workers came to the UK with various visas which shared an explicit prohibition on changing employer. In 1998, a worker-led campaign against generalised abuse, supported by civil society and trade union allies, spurred the creation of a renewable 12-month visa that allowed domestic workers to enjoy statutory employment rights and to apply for indefinite residency after five years (Anderson 2010a). Yet in April 2012, a Conservative-led government acting on an electoral pledge to reduce 'low-skilled' immigration reduced the visa's duration to six months, prohibited renewal and re-tied it to a single employer (Anderson 2013, 172-175). Three years later, an evaluation on these regulations' compatibility with the government's tough stance on 'modern slavery' recommended a reinstatement of the rights to change employer and to renew visas for up to two years and a half (Ewins 2015). The first recommendation was adopted but the second was shelved, with narrow exceptions to enable the prosecution of the most abusive employers (Home Office 2017, 2-3). 
The discussion proceeds as follows. Section 1 lays out a multidimensional normative framework to analyse the types of inequality facing migrant workers, foregrounding theories of justice that decentre citizenship as a condition and ground for moral claims. Section 2 identifies provisions of international soft law and EU law enshrining the principle of equal treatment between national and migrant workers. Sections 3 to 5 illustrate how this principle is systematically violated by interrelated forms of migrant exploitation, domination and stigmatisation. The conclusion recapitulates key ideas and proposes both radical and pragmatic ways to address the national injustice built into migrant worker policies.

\section{Structural injustice, social connection and international mobility}

According to the social connection theory of responsibility (Young 2006), structural injustice arises 'when social processes put large categories of persons under a systematic threat of domination or deprivation of the means to develop and exercise their capacities, at the same time as these processes enable others to dominate or have a wide range of opportunities for developing and exercising their capacities' (Young 2006, 114). This wrong can be distinguished from individual misbehaviour insofar as it is backed by institutional rules and social conventions. While all agents bear responsibility for the structural injustices their actions sustain, they are not necessarily guilty in the sense of having intended to cause harm. Therefore, structural injustice is best remedied not through backward-looking, individual sanctions but through collective attempts to identify and transform the institutions that sustain unjust terms of social cooperation.

Young develops the social connection model to unpack the complicity of Global North consumers, governments and citizens with the exploitation of workers in the Global South, but the perspective it offers can readily be used to analyse the social position of migrant workers residing in the North. In academia and beyond, the critical analysis of this position has so far been inhibited by methodological nationalism, a form of intellectual bias that has circumscribed most theories of justice to the relations among co-citizens (Anderson 2020). In an attempt to overcome this bias, theorists of 'social membership' have proposed to replace citizenship with residence as a criterion for rights attribution, either because residence generates subjection to territorial laws or because it creates social bonds (Walzer 1983; Bosniak 
2006; Carens 2013). Yet since a wide variety of legal statuses prevail even among those who share a formal citizenship, this leaves open the question as to which citizens should provide the measuring rod for the fair treatment of migrants. For instance, children are normally denied active and passive suffrage, and members of the military have limited access to civil courts. Are these arrangements necessarily just, and should they extend to migrants as well? Answering these questions requires us to examine the cumulative impact of the specific bundles of rights and responsibilities attributed to different social categories in a given context (Cohen 2009).

A singularly elegant and comprehensive, though certainly not exhaustive, framework that may be put to this purpose is Nancy Fraser's conception of justice as redistribution, recognition and representation (Fraser 1995, 2000, 2009). This conception foregrounds property, respect and power as core conditions of social participation, and encourages us to unmask their specific but interdependent institutional underpinnings. For example, Fraser proposes that redistribution should mainly but not exclusively be pursued through the transformation of property rights, taxes, welfare systems, trade unions, trade policy and the like; recognition should mainly but not exclusively be advanced through institutionalised communication and cultural patterns; and representation should mainly but not exclusively be achieved through the rules of participation in decision making. When institutional frameworks fail to uphold parity of participation, redistribution, recognition and representation give way to their polar opposites: maldistribution (or exploitation), misrecognition (or stigmatisation) and misrepresentation (or domination). The next sections will unpack how migrant worker policies, notwithstanding their formal commitment to equality, find themselves implicated in all three forms of structural injustice.

\section{Equality principles in migrant worker governance}

The right to equality is enshrined in the International Covenant on Civil and Political Rights and the International Covenant on Economic, Social and Cultural Rights, adopted by the United Nations General Assembly in 1966. Article 2.1 of the former and Article 2.2 of the latter oblige states to uphold the rights of all individuals within their territory and subject to their jurisdiction without distinction of race, colour, language, religion and national origin, among other characteristics. The measures needed to protect migrant workers in particular are set out 
in a series of mutually reinforcing treaties including the International Labour Organization Conventions No. 97, 143 and 189, respectively adopted in 1949, 1975 and 2011, and the United Nations International Convention on the Protection of the Rights of All Migrant Workers and Members of Their Families, adopted in 1990 (Chetail 2019, 200-250). Article 7 of the latter, which is the most comprehensive, enshrines a right to non-discrimination for all migrant workers and members of their families, regardless of their status, in terms very similar to those of the Covenants. However, the Convention goes into greater detail by specifying, in Article 25, that 'migrant workers shall enjoy treatment not less favorable than that which applies to nationals of the State of employment' in respect of remuneration and other working conditions, including overtime, hours of work, weekly rest, holidays with pay, safety, health and termination of employment. To facilitate the exercise of these rights, Article 33 stipulates that migrant workers must receive related information upon request to their states of origin, employment or transit. This information must be provided free of charge and, as far as possible, in a language they understand (see Fudge 2012, 124-126).

Migrant worker conventions have been slow in gathering ratifications from receiving states in the Global North but nevertheless exert considerable influence on global migration policymaking. The International Labour Organization's Multilateral Framework on Labour Migration, a non-binding instrument adopted in 2006 and whose legal value is primarily interpretative, thus reiterates that governments must eliminate all forms of discrimination against migrant workers in employment and occupation (Guideline 8.4.4). In this spirit they must extend labour inspection to all workplaces where these workers are employed (Guideline 10.1), assist them with defending their rights (Guideline 8.2), in particular by offering legal services (Guideline 10.11), interpretation and translation (Guideline 10.10), grant them a reasonable period of time to remain in the country in order to collect any unpaid wages or benefits they may be due (Guideline 9.5), and allow them to lodge complaints and seek remedy without discrimination, intimidation or retaliation (Guideline 10.5) (see Fudge 2012, 126-128).

The Migrant Worker Convention also informed negotiations on the Global Compact for Safe, Orderly and Regular Migration, adopted by the UN General Assembly in December 2018 (Guild, Basaran and Allinson 2019), and the Model International Mobility Convention sponsored by the Columbia Global Policy Initiative (Doyle 2018, 226). These non-binding instruments nevertheless make significant concessions to opponents of migrant worker rights. Both of them 
explicitly allow employer-tied visas for a short period; in addition, the Model Convention gives states discretion to restrict migrants' choice of remunerated activities for up to two years, as well as to limit their right to work to a specific region under certain circumstances (Guild, Basaran and Allinson 2019, 50; Hansen 2018, 292). Within the European area of free movement workers are protected from discrimination on the basis of nationality, but those who are posted abroad by their employers only enjoy a set of core rights (such as minimum remuneration, working time, annual leave, health and safety, and gender equality) on a par with citizens of the state where the work is carried out (Andrijasevic and Novitz 2019, 8-9).

The EU Seasonal Workers Directive shows a greater desire to incorporate human rights standards, in part due to the European Parliament and Council's opposition to the Commission's emphasis on controlling entries during the legislative process (Fudge and Olsson 2014, 463). Article 23 thus establishes the principle of equal treatment between seasonal migrant workers and nationals with respect to working conditions and social security, except in the case of family and unemployment benefits. States must give seasonal migrant workers written information about their rights and complaints procedures (Article 11.2), set up effective mechanisms for them to lodge a complaint against their employers (Article 25) and impose effective, proportionate and dissuasive sanctions against non-compliant employers (Article 17).

While promising on paper, these legal norms can only transform the situation on the ground if effectively mobilised by workers and states in order to prevent employer abuses. A key reason for doubting this can happen is found in Article 14, which obliges seasonal workers to leave their state of employment when their visa expires, after a period of five to nine months (Fudge and Olssen 2014, 456-457). The recent experience of migrant domestic workers in the United Kingdom suggests that the ensuing exposure to illegality and eventual deportation (De Genova 2002) generates forms of oppression that can hardly be reconciled with the Directive's stated aims.

\section{Maldistribution/exploitation}

Boiled down to its essence, maldistribution or exploitation can be defined as an unreciprocated transfer of the fruits of a person's labour to another person. This process is enabled by 'social rules about what work is, who does what for whom, how work is compensated, and the 
social process by which the results of work are appropriated' (Young, 1990, 49-50). Specific forms of exploitation, which Young calls 'menial labour', disproportionately target negatively racialised workers. Menial labour includes the low-paid personal services that domestic workers, bellhops, porters, chambermaids and busboys provide to business executives and government officials, as well as other forms of auxiliary work such as the one labourers perform for welders, electricians and carpenters on a construction site (Young 1990, 52).

The concept of exploitation is typically used to explain economic inequalities that arise in the absence of legally sanctioned class distinctions (Young 1990, 48-49), but throughout the history of capitalism exploitation has gone hand in hand with the denial of legal rights to various categories of workers. Many were defined by their mobility, such as the sailors and soldiers who left Europe in the colonial era, those in West Africa who were enslaved and sold in the triangular trade, and the indentured workers who were recruited from the Indian subcontinent and China to work under criminally enforced contracts on colonial plantations, mines and railways. The profits extracted from these forms of super-exploitation were brought back to Europe and invested in technologies that triggered the industrial revolution and created a large class of dispossessed farmers and redundant artisans: the proletariat (Castles 2015). More recently, the structural adjustment programmes imposed on formally decolonised but globally dominated states by the International Monetary Fund, the World Bank and the World Trade Organisation have extended capitalist control on the means of production to the Global South, creating newly dispossessed and redundant populations (Delgado 2015, 31, 37). To secure a livelihood for themselves and their families, these people often seek to move internally to the cities and regions where the labour-intensive operations of global corporations have been outsourced, or to relocate in the Global North (Delgado 2015, 31-34; O'Connell 2015, 73-75). In both cases they find themselves at the vulnerable end of global supply chains where workers are hired and fired at short notice in line with consumer demand (Andrijasevic and Novitz 2019, 3).

Global and critical analyses of economic relations make clear that migrant worker policies only amount to a small part of the legal apparatus that currently allows the citizens of core states to maintain their economic privileges. They also explain why migrants on temporary work visas disproportionately proceed from societies that have been negatively racialised as non-white. Most importantly for the purpose of this discussion, they make sense of the fact that these migrants regularly consent to conditions of super-exploitation 
often unhistorically and apolitically labelled 'modern slavery' $\left(\mathrm{O}^{\prime} \mathrm{C}\right.$ onnell 2010, 2017). Working patterns may involve excessive work days or hours, unhealthy or dangerous tasks, sub-standard living arrangements, low wages and general disrespect for statutory and contractual norms, as well as more serious rights violations such as confinement, passport confiscation, non-payment and physical violence (Shamir 2017, 491; O'Connell 2010, 249-250; Rosengaertner 2018, 282-283; Andrijasevic and Novitz 2019, 10). Interviews with migrant workers in the UK hotel and catering industry revealed that low pay, unpaid overtime and poor health and safety standards were often seen as normal and inevitable (Wright and Pollert 2006, 2).

Migrant workers' reliance on sending country conditions as a frame of reference to evaluate jobs is often initially linked to their intention to return 'home' to spend or invest their income (Piore 1979, 52-59). For those whose families remain in the country of origin, lesser household commitments may also translate into a greater willingness to work long hours and/or live in with the employer (Anderson 2010b, 305, 308; Anderson and Ruhs 2014, 31), and the acquisition of valued linguistic skills may offset drawbacks (Anderson 2010b, 304). This being said, the looming prospect of illegalisation and deportability (De Genova 2002) plays a determining role in forestalling the development of local attachments, knowledge and aspirations.

In the United Kingdom, migrant domestic workers formally enjoy the same statutory rights as their national counterparts. This includes the minimum wage, whose level more than doubled (to $f 8.72$ an hour for workers aged 25 and over) between 1999 and 2020. In practice, however, the complexity of labour regulations often makes it difficult to identify violations of legal rights. For example, the law establishes a hierarchy between the rights of three types of workers, classified as 'self-employed', 'workers' and 'employees'. Jurisprudentially developed criteria to distinguish between them include a worker's level of control over the content and manner of the work; the potential for profit and business risk incurred; structural integration into the organisation; supply of capital, tools and equipment; any requirement to do work personally rather than through substitutes; and any mutual obligation for the employer to provide work and for the employee to perform it (Collins, Ewing and McColgan 2012, 194). Over the last decades, the steady casualisation of labour relations has generated an increasing number of disputes over employer attempts circumvent legal obligations by manipulating the boundaries between legal statuses. Highly contested practices include 'sham self-employment', agency work and 'zero hour contracts' that leave the employer (and, in theory 
though typically not in practice, the worker) discretion to modify working times at will (Bogg 2012; Royston 2011; Adams, Freedland and Prassl 2015).

The determination of employment rights is further complicated by the variety of status definitions used in different laws. For example, under the Employment Rights Act 1996 the rights not to be unfairly dismissed and to receive redundancy pay can only be exercised after two years of continuous employment, putting them beyond reach of temporary workers. The National Minimum Wage Act 1998 empowers the Secretary of State to exclude from its scope workers under 26 who are within their first six months of employment, who live with their employer or who participate in a training or job-seeking scheme. Under the Fixed-Term Employees Regulation 2002 the right of fixed term employees not to be treated less favorably than permanent ones excludes trainees, apprentices and agency workers employed for less than 12 weeks. The Equality Act 2010 offers anti-discrimination protection to individuals under a contract of employment, a contract of apprenticeship or a 'contract personally to do work', which may include some but not all forms of self-employment. For agency workers, the respective obligations of the agency and the business resorting to its services are often complex to distinguish (Royston 2011; Prassl 2015, 85-88).

Recent migrants' limited knowledge of local institutions and languages, as well as their separation from their support network, makes such complexities extremely difficult to navigate. Unsurprisingly, the above cited study on hotel and catering found many employment relations without contracts or written statements of particulars, as well as little awareness of holiday and leave entitlements (Wright and Pollert 2006, 1). A domestic worker explains:

When I started working in this country, my English was zero, very bad. [My employer] exploited me, f150 a week, Monday to Friday. And then after five years she forced me to work on Saturdays too, without a pay rise. She sent me to her mother's house across the street and said: 'Now when I'm not around with my kids, you have to go see my mum and help her.' But I was afraid to speak because I didn't know my rights and I had no family here. And I thought: 'If I say no, she'll send me back, and where will I go? I don't know where to go. I don't know English, I don't know anything.'

To prevent migrant workers from seeking information on their rights, employers can play on their uncertainties and anxieties, including fears of deportation: 
Employers keep telling workers bad stories: 'If you go out the police will catch you. If there are drunk people on the street they can kill you.' And many things to keep them scared or just hiding. A lady told me that people get drunk at night. She would say: 'Come [to the window] and have a look. This is what I was telling you. People are drunk. If you go out they will kill you.' But [employers] don't care about you. It's just to make them scared to go out. And they're using them. Sometimes employers don't pay them and if something breaks they say: 'You have to pay for it.' With their rubbish salary the worker has to pay.

\section{Misrepresentation/domination}

Migrant workers' generally lower expectations and limited knowledge of local standards is often sufficient for employers to reap outsized benefits from their labour. Yet as the vignettes above suggest, there are also occasions where they become dissatisfied with the conditions on offer and wish to negotiate better ones. In such cases they are likely to find that the powers of immigration enforcement have trickled down into the employment sphere and placed them in a situation of quasi servitude.

Young $(1990,49)$ argues that exploitation is usually underpinned by decision-making structures which lead some people to 'exercise their capacities under the control [and] according to the purposes of others', and that 'coercive structures that give workers few options' enable the unequal exchange of goods (Young 1990, 53). Racialised menial work thus tends to be 'servile and lacking in autonomy, and a person takes orders from many people' (Young 1990, 52). For migrant workers, employer control is enhanced not only by their general obligation to work in order to maintain their right to reside but also, in practice if not in law, by an obligation to remain with the employer who sponsored the visa. This means that this employer simultaneously controls the worker's means of subsistence and their presence in the receiving state (Anderson 2010b, 309; Fudge 2012; O'Connell 2015, 143-145). Little surprise, then, that ease of retention is frequently cited as a key advantage of hiring migrant workers (Anderson 2010b, 310), and that related policies actively create a demand for precarious forms of labour (Anderson and Ruhs 2014, 33-34). This is not to say that employers know the specific rights and obligations attaching to each migration status, as well as the status of all the workers they employ; rather, hiring decisions tend to draw on proxies such as nationality (Anderson and Ruhs 2014, 31, 33). 
Dependence on employers is exacerbated by the fact that migrant workers are routinely denied social benefits (Shutes 2016) and expected to provide for, rather than receive support from, their families and friends (Datta et al. 2007). Those in employer-provided accommodation also risk becoming homeless in the event they lose their job. Stopped from withdrawing their labour, they must turn to alternative ways of challenging employers, such as litigation and collective bargaining (Bogg and Novitz 2014b; Mantouvalou 2014). The problem is that precarious and short-term residence also poses formidable obstacles to these courses of action.

When it comes to legal measures, limited knowledge of substantive law is compounded by procedural hurdles. Research on EU migrant workers has found that they are much less likely than their UK born counterparts to take action against mistreatment at work, as they see this as interfering with the maximisation of short term income. Living on site with limited transport to urban areas, working long or antisocial hours for low pay and having few opportunities to learn English also make it difficult for many migrant workers to enforce rights in court. Language issues are further aggravated by the limited availability of translated procedural information and reduced awareness of free interpretation services. Misunderstandings on the role and functioning of Employment Tribunals may lead to workers fearing that they must pay to discuss the enforcement of their rights; that their right to reside and work may be scrutinised during the proceedings; and that they stand no chance of winning against judicially savvy employers (Barnard, Ludlow and Butlin 2018).

Those who plan to remain in the country for a short period, including seasonal workers, may also be concerned that a judicial dispute will not be resolved before they return (Barnard, Ludlow and Butlin 2018). When asked about the usefulness of Employment Tribunals for migrant domestic workers, an activist explains:

It is hard, because if they're on a six-month visa, they're not even aware, do they have one month left? Do they have two weeks left? Or are their days numbered? [Confiscating passports is a widespread way for employers to restrict the mobility of migrant domestic workers.] So how could they possibly claim their rights? Say they have unpaid wages. Those six months would not give them time to claim their rights.

According to this respondent, the time factor is so determining that six-month, non-renewable visas de facto amount to a denial of all employment rights. In addition to the waiting periods built into legal 
procedures, time scarcity can stem from the long and unpredictable hours that come with precarious work as well as the effort needed to satisfy basic needs with minimal financial resources. An analysis of legal cases involving migrant workers found they often struggled to describe problems clearly or present adequate evidence in a timely way (Barnard 2014, 212).

For legal assistance, workers can resort to Citizens Advice Bureaux, a state funded charity that delivers services in some 600 local offices through 7,000 employees and 23,000 volunteers (Citizens Advice $2017,2)$. Depending on locally available resources, advice can be provided by generalists with or without specific employment training, in-house solicitors, pro bono solicitors or collaborating law centres (Busby and McDermont 2012). However migrant workers have been found to rely primarily on co-national friends and colleagues for legal advice and to ignore the existence of institutionalised forms of support (Barnard, Ludlow and Butlin 2018, 238, 243).

Given that most employment arrangements are contract based and created through a negotiation between the parties involved, especially in the highly deregulated British labour markets, collective bargaining is another important way for workers to push back against exploitative conditions. Yet the dramatic decline in union membership witnessed since the beginning of the 1980s has disproportionately affected the precarious sectors and occupations where migrants tend to cluster (Ruhs and Anderson 2014). In 2016, only $13.4 \%$ of private sector employees were affiliated to a union, compared to $52.7 \%$ for their public sector counterparts. While $38.4 \%$ of professionals were unionised, this figure dropped to $21.2 \%$ for other employees. About one in three employees earning between $£ 2,000$ and $£ 4,000$ per month was a union member, compared to $12.3 \%$ for those earning less than $£ 1,000$ per month. In the accommodation and food sector, membership was as low as 2.5\% (Department of Business, Energy and Industrial Strategy 2017, 23-24). Even in organised workplaces, unions may be reluctant to develop tailored recruitment campaigns and services for migrants and other transient workers (Fitzgerald and Hardy 2010, 133, 145; Eldring, Fitzgerald and Arnholtz 2012; Alberti, Holgate and Tapia 2013, 4144-4145), or to place them in leadership positions (Lillie and Sippola 2011, 295). Tied visas can also make migrant workers fearful of antagonising their employer by joining a union (Bogg and Novitz 2014a, 363), and the ETHOS study found that some domestic workers used language classes as a cover for union activities. As for litigation, financial hardship, transitory residence and limited local knowledge can constitute important 
impediments to migrant workers joining a union (Anderson, Clark and Parutis 2007).

\section{Misrecognition/stigmatisation}

As Young $(1990,52)$ observes, the exploitation and domination of menial labour frequently lead to its merit being claimed by those who extract it. In this way, the power-laden transfer of goods from the have-nots to the haves goes hand in hand with an equivalent transfer of status. A key mechanism through which this takes place is the concealment of the tasks associated with low paid jobs and the constant redefinition of 'skills' so as to exclude the capacities required to perform them (Phillips and Taylor 1980; Anderson 2013, 58-61). When negatively racialised migrant workers toil in economic sectors and occupations that are low paid and therefore seen as low skilled, their national category becomes further stereotyped as lacking in competence (Fiske et al. 2002). In addition to a widespread tendency to attribute people's situation and actions to individual rather than structural factors (Gilbert and Malone 1995), stereotyping may be driven by a motivation to explain inequalities so as to sustain a belief in a broadly just world (Lerner and Miller 1978) or to keep one's outgroup in a subordinate position (Berger, Rosenholtz and Zelditch 1980; Anderson 2000, 152-158).

The stigmatisation of menial work, and particularly work associated with the body and dirt (Anderson 2000, 141-142) explains why employer abuse can take the form of requiring the unnecessary performance of such tasks, as a migrant worker illustrates:

One day, [the employer's] son comes with his shoes in one hand and says: 'Look, I want you to wash it from here.' And I was thinking: 'What kind of domestic work is this? Why should I wash the bottom of his shoes?' I've been here almost two years. I've never touched any shoes. Why does he come now asking me to wash them from the bottom?'

This worker also explains her feeling of humiliation at being assigned by her wealthy employer to live in a windowless storage room without heating or air conditioning:

I was shocked, but I couldn't speak because my visa was about to expire and I had to renew it. So I had to remain silent. When the visa arrived, I opened my eyes and I said: 'Sorry but this is very bad, 
the carpet is dirty, the walls need to be repainted, there are several things that need to change because I am not well.' [...] And then, after that, [the employer] gave me the duvet that her 33 year old son was using when he was a child. Look at me, and she gave me the single one, the small one for the children. So I went to West London and I bought a fabric and a sewing machine, and I did everything. I did the curtain, I did the bed, I did the cover, everything. [...] When [the employer] came to my room, she just went: [looking up and down with a mix of surprise and disdain] 'How come!' You know, they treat us like animals. She was looking like: 'What? How come you have all this settled and clean?'

Once negative attitudes toward migrant workers have become ingrained, it may be tempting for state officials and other influential actors to manipulate them for political purposes. One discursive tool that has been successfully deployed to bolster the civilisational credentials of core capitalist states is the figure of the victim of 'trafficking' and 'modern slavery'. Article 3 of the United Nations Protocol on Trafficking in Persons, adopted in 2000, defines this as someone who is transported for the purpose of exploitation by the use of threats, force, coercion, abduction, fraud, deception or abuse of power. Anti-trafficking discourses tend to be highly paternalistic in tone, drawing on racialised and gendered stereotypes of victimhood. Gendered racialisation takes place through a strong emphasis on abused bodies and patriarchal cultures that maintain Southern female workers in poverty and ignorance. Tracing a bright line between Northern modernity, agency and rationality and Southern objectification, traditionalism and emotivism, these discourses usually represent exploitative traffickers as foreigners who seek to import corrupt employment practices. When the 'victims' themselves speak in public fora, they are only believed insofar as they reproduce such portrayals and refrain from showing any signs of anger or political engagement (Anderson and Andrijasevic 2008; Anderson 2013, 137152; O'Connell 2010, 255-257). Commenting on a special mechanism that allows those recognised as victims of modern slavery to extend their residence, the activist asks: 'Why do we have to be raped, beaten, left to starve in order to be protected? Why do we have to go so far?'

Like the 'victim' of trafficking and modern slavery, the 'economic migrant' is typically depicted as lacking in skills and competence, but far from being embedded in oppressive social relations, this deeply masculine figure is portrayed as a free actor seeking to maximise the returns on their labour. Hence whereas the victim of trafficking becomes an object of pity through the politics of culture 
and civilisation, the economic migrant becomes a target of hostility through the politics of labour. Bonacich $(1972,549)$ defines a 'split' labour market as containing 'at least two groups of workers whose price of labour differs for the same work, or would differ if they did the same work.' In keeping with the analysis presented in Sections 4 and 5, she observes that this price difference may be due to the economic system of migrant workers' country of origin, to the political and social support they have at their disposal, or to the information they hold on local standards. It can also be due to their temporariness and wish to avoid spending time and energy on longer term political mobilisation (Bonacich 1972, 551). Racial and ethnic inequalities arise as a by-product of the global correlation between race/ethnicity and the distribution of economic resources (Bonacich 1972, 552). In such a context, a structural conflict develops between high paid workers on the one hand, and employers and cheaper migrant workers on the other hand. While the interests of the latter two groups tend to converge, high paid workers tend to fear that their bargaining position will be weakened by the availability of a docile workforce willing to replace them (Bonacich 1972, 553). To forestall undercutting they can deploy strategies of exclusion or caste. Exclusion consists in preventing the participation of migrant workers in the economic system, whereas caste consists in maintaining national workers' monopoly on high paid jobs. Caste systems perpetuate themselves through laws, customs and beliefs aiming to keep migrant workers and their racialised offspring in a subordinate position. When those categorised as such try to secure scarce social goods, high paid workers may feel that their rightful property is being encroached upon and that subordinates are 'getting out of place' (Bonacich 1972, 155; see also Bobo 1999).

The stigmatising effect of such labour conflicts vividly came to light in 2009 when engineering construction workers at the Lindsey Oil Refinery in Northern England took unofficial strike action against the subcontracting of 200 Italian and Portuguese workers to build a desulphurisation plant. British workers complained that they had been contracted to circumvent existing collective agreements, for instance in relation to paid breaks and preparation time. Part of the reason why the dispute eventually grabbed national and international attention was the slogan chosen by the protesters, 'British jobs for British workers', which echoed a speech made by then Prime Minister Gordon Brown at the 2007 Labour Party conference. Adopted and promoted by senior trade union figures, this slogan catalysed solidarity action involving approximately 4000 workers throughout the country. Comments on an on-line forum set up by the strikers revealed strongly xenophobic 
attitudes among some participants, one of whom expressed a wish that foreign workers would 'fuck off back home and take their sponging gippo [Gypsy] families with them... My family has fought in world wars for this country, and I bet they didn't do it so we could be shafted by ethnics and eastern Europeans'. A recurring trope was that foreign workers lacked the necessary accreditations and skills to carry out the work, and that this would not only run against effectiveness and efficiency concerns but also threaten health and safety: 'Lifting great sheets of fabricated plate with just plate grabs, no pinkies, no chains, no shackles, unbelievable. This is par for the course with these socalled skilled men, we've all seen them, in my opinion they are at best semi-skilled, at worst killers.' The dispute resulted in the earmarking of contracts for British workers, after which Gordon Brown issued a statement highlighting professional requests for employers to consider hiring competent local workers before resorting to foreign contractors (Ince et al. 2015).

\section{Conclusion}

Can migrant worker policies ever be just? The theory and evidence presented in this chapter suggest a negative answer, at least in the case of low paid workers from the Global South. Far from enabling equal opportunities for everyone to develop and exercise their capacities, these policies push racialised migrants' working conditions downwards; prevent them from leaving their employer, enforcing their rights in court or mobilising in unions; and exacerbate racial conflict and stereotyping. Insofar as these conclusions can be extrapolated beyond the occupations and contexts examined here, labour shortages should be addressed through alternative means such as the training of national workers, the improvement of working conditions, technological innovation or fair international trade (see Anderson and Ruhs 2014, 19).

The social connection model of responsibility proposes that everyone, but especially those who benefit from injustice or have the knowledge and capacity to reverse it, should take action against the institutionalised practices that perpetuate it. What sort of change could excise the national exploitation, domination and stigmatisation linked to migrant worker policies? A radical option would be to eliminate these policies altogether, for instance by delivering open-ended visas to all foreign workers or, less ambitiously, replacing short term conditional visas with renewable ones that do not require continuous employment. 
This would go a long way in addressing problems of lower worker expectations, linguistic disadvantage, judicial delays and marginalisation from unions. As long as recognisable migrant worker policies remain, however, more pragmatic tweaks could be voted into law or required by the courts interpreting human rights. For instance, the principle of equal treatment between national and migrant workers could be extended beyond statutory rights and brought to bear on contractually agreed working conditions as well as informal arrangements. In keeping with the idea of differentiated citizenships, the disadvantages of temporary stay could be offset through stronger rights in some areas, such as the minimum wage and protection against dismissal. In the immediate future, labour inspectorates could ensure that existing standards are upheld even in the most isolated workplaces, including remote farms and factories and private homes employing domestic workers. Where union membership has been falling, collective labour law could be reformed so as to make collective bargaining the rule rather than the exception throughout the economy. The magnitude of such changes, and the political opposition they are likely to face, goes to show how far from global justice migrant worker policies and other capitalist forms of economic governance have allowed us to stray.

\section{Bibliography}

Adams, Abi, Mark Freedland, and Jeremias Prassl. 2015. "The 'zero-hours contract': Regulating casual work, or legitimating precarity?», ELLN Working Paper 2/2015.

Alberti, Gabriella, Jane Holgate, and Maite Tapia. 2013. "Organising migrants as workers or as migrant workers? Intersectionality, trade unions and precarious work.» The International Journal of Human Resource Management 24, no. 22: 4132-4148.

Anderson, Bridget. 2000. Doing the dirty work? The global politics of domestic labour. London: Zed Books.

Anderson, Bridget. 2010a. "Mobilizing migrants, making citizens: Migrant domestic workers as political agents.» Ethnic and Racial Studies 33, no. 1: 60-74.

Anderson, Bridget. 2010b. «Migration, immigration controls and the fashioning of precarious workers.» Work, Employment et Society 24, no. 2: 300-317.

Anderson, Bridget. 2013. Us \& Them? The dangerous politics of immigration control. Oxford: Oxford University Press.

Anderson, Bridget. 2020. "Justice, citizenship, and methodological denationalism.» In Justice and vulnerability in Europe: An interdisciplinary approach, edited by Trudie Knijn and Dorota Lepianka, 125-142. Cheltenham: Edward Elgar. 
Anderson, Bridget and Rutvica Andrijasevic. 2008. "Sex, slaves and citizens: The politics of anti-trafficking. » Soundings 40: 135-145.

Anderson, Bridget, Nick Clark and Violetta Parutis. 2007. New EU members? Migrant workers' challenges and opportunities for UK trades unions: A Polish and Lithuanian case study. TUC/COMPAS.

Anderson, Bridget and Martin Ruhs. 2013. "Migrant workers: Who needs them? A framework for the analysis of staff shortages, immigration, and public policy.» In Who needs migrant workers? Labour shortages, immigration, and public policy, edited by Martin Ruhs and Bridget Anderson, 15-56. Oxford: Oxford University Press.

Andrijasevic, Rutvica and Tonia Novitz. 2019. "Supply chains and unfree labor: Regulatory failure in the case of Samsung Electronics in Slovakia.» Journal of Human Trafficking 6, no. 2: 195-208.

Balibar Étienne and Immanuel Wallerstein. 1991. Race, nation, class: Ambiguous identities. London: Verso.

Barnard, Catherine. 2014. «Enforcement of employment rights by migrant workers in the UK.» In Migrants at work: Immigration and vulnerability in labour law, edited by Cathryn Costello and Mark Freedland, 193-215, Oxford: Oxford University Press.

Barnard, Catherine, Amy Ludlow, and Sarah Butlin. 2018. "Beyond employment tribunals: Enforcement of employment rights by EU-8 migrant workers. » Industrial Law Journal 47, no. 2: 226-262.

Berger, Joseph, Susan J. Rosenholtz and Morris Zelditch. 1980. "Status organizing processes. » Annual Review of Sociology 6: 479-508.

Bobo, Lawrence D. 1999. «Prejudice as group position: Microfoundations of a sociological approach to racism and race relations.» Journal of Social Issues 55, no. 3: 445-472.

Bogg, Alan. 2012. "Sham self-employment in the Supreme Court.» Industrial Law Journal 41, no. 3: 328-345.

Bogg, Alan and Tonia Novitz. 2014a. "Links between individual employment law and collective labour law: Their implications for migrant workers.» In Migrants at work: Immigration and vulnerability in labour law, edited by Cathryn Costello and Mark Freedland, 361-380. Oxford: Oxford University Press.

Bogg, Alan and Tonia Novitz. 2014b. «The purposes and techniques of voice: Prospects for continuity and change.» In Voices at work: Continuity and change in the Common Law world, edited by Alan Bogg and Tonia Novitz, 3-34, Oxford: Oxford University Press.

Bonacich, Edna. 1972. "A theory of ethnic antagonism: The split labour market.» American Sociological Review 37, no. 5: 547-559.

Bosniak, Linda. 2006. The citizen and the alien: Dilemmas of contemporary membership. Princeton: Princeton University Press.

Busby, Nicole and Morag McDermont. 2012. "Workers, marginalized voices and the Employment Tribunal system: Some preliminary findings.» Industrial Law Journal 41, no. 2: 166-183.

Carens, Joseph. 2013. The ethics of immigration. Oxford: Oxford University Press. 
Castles, Stephen. 2006. «Guestworkers in Europe: A resurrection?», International Migration Review 40, no. 4: 741-766.

Castles, Stephen. 2015. "Migration, precarious work, and rights.» In Migration, precarity, and global governance: Challenges and opportunities for labour, edited by Carl-Ulrick Shierup, Ronaldo Munck, Branka LikicBrboric and Anders Neergaard, 46-66. Oxford: Oxford University Press.

Chetail, Vincent. 2019. International Migration Law. Oxford: Oxford University Press.

Citizens Advice. 2017. Annual Report 2016/2017 Accessed May 16 https:// www.citizensadvice.org.uk/Global/CitizensAdvice/citizens \%20advice \% 20 annual\%20report.pdf.

Collins, Hugh, Keith D. Ewing, and Aileen McColgan. 2012. Labour Law. Cambridge: Cambridge University Press.

Cohen, Elizabeth F. 2009. Semi-citizenship in democratic politics. Cambridge: Cambridge University Press.

Datta, Kavita, Cathy Mcllwaine, Jane Wills, Yara Evans, Joanna Herbert, and Jon May. 2007. "The new development finance or exploiting migrant labour? Remittance sending among low-paid migrant workers in London.» International Development Planning Review 29, no. 1: 43-67.

De Genova, Nicholas. 2002. "Migrant 'illegality' and deportability in everyday life.» Annual Review of Sociology 31: 419-447.

Delgado, Raúl. 2015. «Migration and labour under neoliberal globalization.» In Migration, precarity, and global governance: Challenges and opportunities for labour, edited by Carl-Ulrick Shierup, Ronaldo Munck, Branka LikicBrboric, and Anders Neergaard, 25-45. Oxford: Oxford University Press.

Department of Business, Energy \& Industrial Strategy. 2017. Trade union membership 2016: Statistical bulletin Accessed May 15 https://assets. publishing.service.gov.uk/government/uploads/system/uploads/ attachment_data/file/616966/trade-union-membership-statistical-bulletin2016-rev.pdf

Doyle, Michael. 2018. "The Model International Mobility Convention.» Columbia Journal of Transnational Law 56, no. 2: 219-237.

Dupont, Pier Luc. 2018. "Arguments socio-juridiques pour l'interdiction des politiques de travailleur migrant à la lumière des droits à l'égalité et l'accès à la justice.»In Immigration, diversité ethnoculturelle et citoyenneté, edited by Leila Celis and Victor Reyes Bruneau, 55-75. Montreal: Les Cahiers du CRIEC 44.

Dupont, Pier-Luc and Bridget Anderson. 2018. UK report on the economic struggles of young mothers and migrant domestic workers. ETHOS WP 6.2.

Eldring, Line, lan Fitzgerald, and Jens Arnholtz. 2011. "Post-accession migration in construction and trade union responses in Denmark, Norway and the UK. » European Journal of Industrial Relations 18, no. 1: 21-36.

Ewins, James. 2015. Independent review of the overseas domestic worker visa Accessed May 15 https://assets.publishing.service.gov.uk/government/ uploads/system/uploads/attachment_data/file/486532/ODWV_Review_-_ Final_Report_6_11_15_.pdf 
Fanon, Frantz. 1952. Black skins, white masks. Sydmouth: Pluto Press.

Fiske, Susan T., Amy J.C. Cuddy, Peter Glick, and Jun Xu. 2002. "A model of (often mixed) stereotype content: Competence and warmth respectively follow from perceived status and competition.» Journal of Personality and Social Psychology 82, no. 6: 878-902.

Fitzgerald, lan and Jane Hardy. 2010. «Thinking outside the box? Trade union organizing strategies and Polish migrant workers in the United Kingdom.» British Journal of Industrial Relations 48, no. 1: 131-150.

Fraser, Nancy. 1995. «From redistribution to recognition? Dilemmas of justice in a 'post-socialist' age.» New Left Review I/212: 68-93.

Fraser, Nancy. 2000. "Rethinking recognition.» New Left Review 3: 107-120.

Fraser, Nancy. 2009. Scale of justice: Reimagining political space in a globalizing world. New York: Columbia University Press.

Fudge, Judy. 2012. "Precarious migrant status and precarious employment: The paradox of international rights for migrant workers.» Comparative Labour Law \& Policy Journal 34: 95-132.

Fudge, Judy, and Petra Herzfeld Olsson. 2014. «The EU Seasonal Workers Directive: When immigration controls meet labour rights.» European Journal of Migration and Law 16: 439-466.

Gilbert, Daniel T. and Patrick S. Malone. 1995. «The correspondence bias.» Psychological Bulletin 117, no. 1: 21-38.

Goldberg, David T. 1993. Racist culture. Oxford: Blackwell.

Guild, Elspeth, Tugba Basaran, and Kathryn Allinson. 2019. «From zero to hero? An analysis of the human rights protections within the Global Compact for Safe, Orderly and Regular Migration (GCM).»International Migration 57, no. 6: 43-59.

Hansen, Randall. (2018) «Labour migration and international mobility: Normative principles, political constraints.» Columbia Journal of Transnational Law 56, no. 2: 289-295.

Home Office. 2017. Domestic workers in private households Accessed May 15. https://assets.publishing.service.gov.uk/government/uploads/system/ uploads/attachment_data/file/602790/Domestic-workers-in-privatehouseholds-v17_0ext.pdf

Ince, Anthony, David Featherstone, Andrew Cumbers, Danny MacKinnon and Kendra Strauss. 2014. "British jobs for British workers? Negotiating work, nation, and globalisation through the Lindsey Oil Refinery disputes.» Antipode 47, no. 1: 139-157.

Lerner, Melvin J. and Dale T. Miller. 1978. "Just world research and the attribution process: Looking back and ahead.» Psychological Bulletin 85, no. 5: 1030-1051.

Lillie, Nathan and Markku Sippola. 2011. "National unions and transnational workers: The case of Olkiluoto 3, Finland.» Work, Employment and Society 25, no. 2: 292-308.

Mantouvalou, Virginia. 2014. "Democratic theory and voices at work.» In Voices at work: Continuity and change in the Common Law world, edited by Alan Bogg and Tonia Novitz, 3-34. Oxford: Oxford University Press. 
Medland, Lydia. 2017. «Misconceiving 'seasons' in global food systems: The case of the EU seasonal workers directive.» European Law Journal 23: 157-171.

Mills, Charles W. 1997. The racial contract. London: Cornell University Press.

Novitz, Tonia and Rutvica Andrijasevic. 2020. "Reform of the posting of workers regime - An assessment of the practical impact on unfree labour relations.» Journal of Common Market Studies 58, no. 5: 1325-1341.

O'Connell, Julia. 2010. "New slavery, old binaries: Human trafficking and the borders of 'freedom'.» Global Networks 10, no. 2: 244-261.

O'Connell, Julia. 2015. Modern slavery: The margins of freedom. New York: Palgrave Macmillan.

O'Connell, Julia. 2017. "The Right to Locomotion? Trafficking, Slavery and the State.» In Revisiting the law and governance of trafficking, forced labor and modern slavery, edited by P. Kotiswaran, 157-178. Cambridge: Cambridge University Press.

Piore, Michael J. 1979. Birds of passage: Migrant labor and industrial societies. Cambridge: Cambridge University Press.

Phillips, Anne and Barbara Taylor. 1980. "Sex and skill: Notes towards a feminist economics.» Feminist Review 6, no. 1: 79-88.

Prassl, Jeremias. 2015. The concept of the employer. Oxford: Oxford University Press.

Rosengaertner, Sarah. 2017. "Pathways to protection and permanency: Towards regulated global economic migration and mobility.» Columbia Journal of Transnational Law 56, no. 2: 280-288.

Royston, Tom. 2011. "Agency workers and discrimination law: Muschett v HM Prison Service.» Industrial Law Journal 40, no. 1: 92-102.

Ruhs, Martin. 2006. "The potential of temporary migration programmes in future international migration policy.» International Labour Review 145, no. 1-2: 7-36.

Ruhs, Martin, and Bridget Anderson (eds). 2014. Who needs migrant workers? Labour shortages, immigration, and public policy. Oxford: Oxford University Press.

Shamir, Hila. 2017. "The paradox of 'legality': Temporary migrant worker programs and vulnerability to trafficking.» In Revisiting the law and governance of trafficking, forced labour and modern slavery, edited by Prabha Kotiswaran, 471-502. Cambridge: Cambridge University Press.

Shutes, Isabel. 2016. "Work-related conditionality and the access to social benefits of national citizens, EU and non-EU citizens.» Journal of Social Policy 45, no. 4: 691-707.

Van Nuffel, Piet and Sofia Afanasjeva. 2018. "The Posting of Workers Directive revised: Enhancing the protection of workers in the cross-border provision of services.» European Papers 3, no. 3: 1401-1427.

Walzer, Michael. 1983. Spheres of justice: A defense of pluralism and equality. Basic Books.

Wright, Tessa, and Anna Pollert. 2007. "The experience of ethnic minority workers in the hotel and catering industry: Routes to support and advice on workplace problems.» ACAS Research Paper 03/06. 
Young, Iris Marion. 1990. Justice and the politics of difference. Princeton: Princeton University Press.

Young, Iris Marion. 2006. "Responsibility and global justice: A social connection model.» Social Philosophy and Policy 23, no. 1: 102-130. 


\section{Copyright}

Deusto Journal of Human Rights / Revista Deusto de Derechos Humanos is an Open Access journal; which means that it is free for full and immediate access, reading, search, download, distribution, and reuse in any medium only for non-commercial purposes and in accordance with any applicable copyright legislation, without prior permission from the copyright holder (University of Deusto) or the author; provided the original work and publication source are properly cited (Issue number, year, pages and DOI if applicable) and any changes to the original are clearly indicated. Any other use of its content in any medium or format, now known or developed in the future, requires prior written permission of the copyright holder.

\section{Derechos de autoría}

Deusto Journal of Human Rights / Revista Deusto de Derechos Humanos es una revista de Acceso Abierto; lo que significa que es de libre acceso en su integridad inmediatamente después de la publicación de cada número. Se permite su lectura, la búsqueda, descarga, distribución y reutilización en cualquier tipo de soporte sólo para fines no comerciales y según lo previsto por la ley; sin la previa autorización de la Editorial (Universidad de Deusto) o la persona autora, siempre que la obra original sea debidamente citada (número, año, páginas y DOI si procede) y cualquier cambio en el original esté claramente indicado. Cualquier otro uso de su contenido en cualquier medio o formato, ahora conocido o desarrollado en el futuro, requiere el permiso previo por escrito de la persona titular de los derechos de autoría. 